\title{
Susceptibility of Bacteria Isolated from Air-Conditioning System Ducts to Different Ultraviolet Radiation Doses
}

\author{
Amira Hassan Al-abdalall ${ }^{*}$ (D), Sarah Abdullah Al-dakheel ${ }^{2}$ and \\ Hmidah Abdulhadi Al-Abkari ${ }^{1}$ \\ ${ }^{1}$ Department of Biology, ${ }^{2}$ Department of Physics, Imam Abdurrahman Bin Faisal University, Dammam, \\ Kingdom of Saudi Arabia.
}

\begin{abstract}
Several bacteria exist in the air that pass through the ducts of air-conditioning systems. This study aimed to determine the effect of ultraviolet germicidal irradiation (UVGI) on six bacterial isolates (Serratia liquefaciens, Bacillus pumilus, Bacillus cereus, Staphylococcus lentus, Bacillus subtilis, and Oligella ureolytica) from the in-duct of an air-conditioning system. Bacterial species were exposed to UVGI with a wavelength of $264 \mathrm{~nm}$ for different durations. The exposed samples were then cultured and evaluated for growth. Growth was evaluated based on the colony-forming units, and the number of bacterial cells was estimated using spectrophotometry. Thereafter, the susceptibility value ( $Z$ value) to the UVGI was calculated for each bacterium. Each bacterium showed a different $Z$ value under the same UVGI conditions, depending on the gram characteristics of the bacterium. The findings confirmed that UVGI is a potent technique for reducing the growth rate of multiple species of bacteria isolated from air-conditioning systems and this reduction depends on the structure of the bacteria (gram +ve and gram -ve) as well as exposure time. UV lamps can be placed in air-conditioning ducts to reduce or prevent the transmission of bacteria into the environment.
\end{abstract}

Keywords: Ultraviolet Radiation, bacteria, susceptibility, Air-Conditioning System.

*Correspondence: aalabdalall@iau.edu.sa

(Received: 02 June 2019; accepted: 06 July 2019)

Abbreviations: Ultraviolet Germicidal Irradiation (UVGI), susceptibility (Z), Light dose (D), Air conditioning (AC), Intensity of light (I), Power of the lamp (P), Distance between the lamp and the bacteria sample ( $r$ ), Statistical Package for the Social Sciences (SPSS), Concentration of bacterium (C), Gram-negative (-Gm), Gram-positive (+Gm).

Citation: Amira Hassan Al-abdalall, Sarah Abdullah Al-dakheel and Hmidah Abdulhadi Al-Abkari, Susceptibility of Bacteria Isolated from Air-Conditioning System Ducts to Different Ultraviolet Radiation Doses, J Pure Appl Microbiol., 2019; 13(4):2383-2388. https://doi.org/10.22207/JPAM.13.4.54

(C) The Author(s) 2019. Open Access. This article is distributed under the terms of the Creative Commons Attribution 4.0 International License which permits unrestricted use, sharing, distribution, and reproduction in any medium, provided you give appropriate credit to the original author(s) and the source, provide a link to the Creative Commons license, and indicate if changes were made. 


\section{INTRODUCTION}

Living in a healthy environment is an absolute necessity for a wholesome human life. However, this target cannot be achieved without sterilizing the air that passes through the ducts of the now widely used air conditioning (AC) systems, since these ducts connect the outdoor and indoor environments and allow bacteria and other harmful microorganisms to reach human bodies and cause health problems (Thrasher and Crawley 2009; Cowling et al. 2013 and Antusheva et al. 2016) $)^{1-3}$.

There is a HEPA filter that has a highly efficient to capture the airborne microbes of different diameters to provide a fresh and clean air ${ }^{16,21}$. The major problem in this technic is once the $A C$ turns off the microbes will find an excellent environment to increase because this filter does not kill the microbes only keep them from passing to the indoor. In contract, using the ultraviolet germicidal irradiation (UVGI) in the AC duct eliminates the airborne microbes (Bintsis et al, 2000; VanOsdell and Foarde 2002; Rudnick et al. 2009 And Ryan et al. 2010) ${ }^{4-7}$, especially in laboratories and medical facilities that require high standards of air quality (Brickner et al. 2003) . The $^{2}$ wavelength of the light used in this study is in the greatest absorption range for DNA of microbial cells, that is, 260-265 $\mathrm{nm}$ (Courcelle and Hanawalt 2001) $)^{9}$.

Lopez-Malo \& Palou 2005 reported that the bactericidal effect of ultraviolet (UV) radiation is due to the shift in electrons caused by photons, which breaks the links in DNA (Lopez-Malo and Palou, 2005 $)^{10}$. Furthermore, UV irradiation can reduce the indoor concentration of airborne bacteria (Kujundzic et al. 2006) ${ }^{11}$; it has been observed that placing a UV light source in the duct of air conditioning systems can reduce the microbial concentration by $99.9 \%$ (Yassin and Almouqatea 2010) ${ }^{12}$.

Different doses of UV radiation are required to cause damage to the different types of microbes in the air (Hijnen et al. 2006) ${ }^{13}$. Lai et al. studied the UV radiation dose versus the survival of Serratia marcescens bacteria in 5 different suspending media and recognized that they were most susceptible to UV irradiation in water media (Lai et al. 2003) ${ }^{14}$. Another study examined the disinfection efficacy of different UV intensities on five airborne pathogens and experimentally determined the Z-values (Yang et al. 2018) ${ }^{15}$.

This study aimed to use an effective and safe technology for air disinfection by applying ultraviolet germicidal lamps in air-conditioning ducts. To improve the efficiency of indoor air quality and for whole room disinfection, the effect of UVGI on five bacteria (Serratia liquefaciens, Bacillus pumilus, Bacillus cereus, Staphylococcus lentus, Bacillus subtilis, and Oligella ureolytica) that have not been studied for their susceptibility value (Z-values) to UVGI, was studied.

\section{MATERIALS AND METHODS}

\section{Experimental design}

As shown in Fig. 1, a small wooden chamber $(70,50,50 \mathrm{~cm})$ consisting of a UV lamp (TOSHIPA/ 15WATTS GERMICIDAL GL 15, the output power $=4.9 \mathrm{~W}$ ) emitting light with wavelength of $264 \mathrm{~nm}$ was used for exposing the

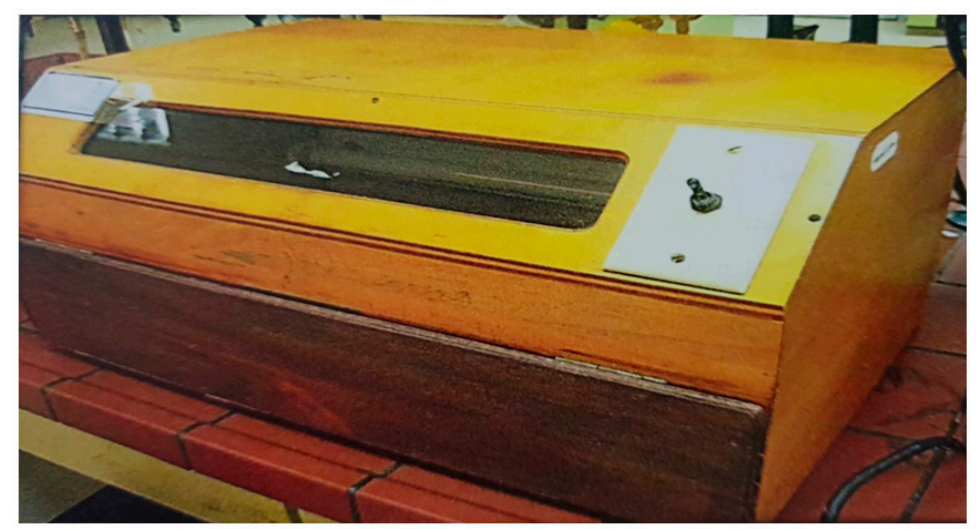

Fig. 1. The wooden chamber containing the UV lamp in its ceiling and the bacteria sample placed at the bottom. 
bacteria to UV (Fig. 1). The lamp was placed on the ceiling of the chamber, $15 \mathrm{~cm}$ from the bacterial samples.

Six species of bacteria (S. liquefaciens, S. lentus, B. subtilis, B. cereus, O. ureolytica, and $B$. pumilus), which were the most abundant bacteria in the $A C$ duct, were isolated during the summer season in 2009, from air conditioning systems (homes, schools, hospitals, and shopping centers) in the eastern region of Saudi Arabia (Al-abdalall and Al-abkari 2017: Al-abdalall et al. 2019) ${ }^{16-17}$, and cultured on nutrient agar media for $24 \mathrm{~h}$ at $37^{\circ} \mathrm{C}$. Bacterial isolates were preserved purely on NA slants.

\section{Purification \& identification of isolates}

These bacterial strains were identified in the laboratories of Qatif Hospital using BD Phoenix, an automated system for rapid identification of bacteria and for determination of antimicrobial susceptibility to antibiotics. Up to 100 phenotypic tests lead to the ID of microorganisms.

Six bacterial isolates were inoculated in nutrient broth medium separately, and incubated at $37^{\circ} \mathrm{C}$ for $24 \mathrm{~h}$. Then, bacterial suspensions in $2 \mathrm{~mL}$ of Tween 80 per $100 \mathrm{~mL}$ distilled water were prepared by transferring $1 \mathrm{ml}$ of the abovementioned solution to a test tube content $9 \mathrm{ml}$ of the microbial liquid culture and this step was repeated twice to obtain a dilution $\left(10^{-2}\right)$. After the exposure, $0.1 \mathrm{~mL}$ of the bacterial suspensions was transferred to tubes containing $5 \mathrm{~mL}$ of mannitol agar (10 g tryptone $+10 \mathrm{~g}$ yeast extract
+ $5 \mathrm{~g}$ mono hydrogen dipotassium phosphate +3 g mannitol+20 g agar) media1 and incubated at $37^{\circ} \mathrm{C}$ for $24 \mathrm{~h}$. (Al-abkari 2014) $)^{18}$.

The UV light dose (Depends on the power of the light and light running time) was calculated using the following equation:

$D=$ Intensity of UV $\left[\frac{\mathrm{w}}{\mathrm{cm}^{2}}\right] \times$ Time of Exposure (s)

Where the intensity could be determined from the power of the lamp and the distance between the lamp and the bacterial sample as shown below:

$$
\mathrm{I}=\frac{\mathrm{P}}{4 \pi^{2}}=\frac{4.9[\mathrm{~W}]}{4 \times 3.14 \times(15 \mathrm{~cm})^{2}}=0.0017\left[\frac{\mathrm{W}}{\mathrm{cm}^{2}}\right]
$$

\section{Experimental procedure}

The bacteria samples were exposed to UV light for different exposure times $(5,10,15$, $20,60,180$, and $360 \mathrm{~min})$. The experiment was repeated three times and the average of the bacterial concentrations (number of colonies) was calculated using SPSS 16 . The concentrations of the bacteria before and after UV exposure were used to calculate the susceptibility (Z) of the bacteria to UV exposure (245 nm)

The number of bacterial cells estimated was measured as described before (Didier et al. $2001)^{19}$, using a spectrophotometer to measure the absorbance at a wavelength of $600 \mathrm{~nm}$, and then compared with those of the untreated control

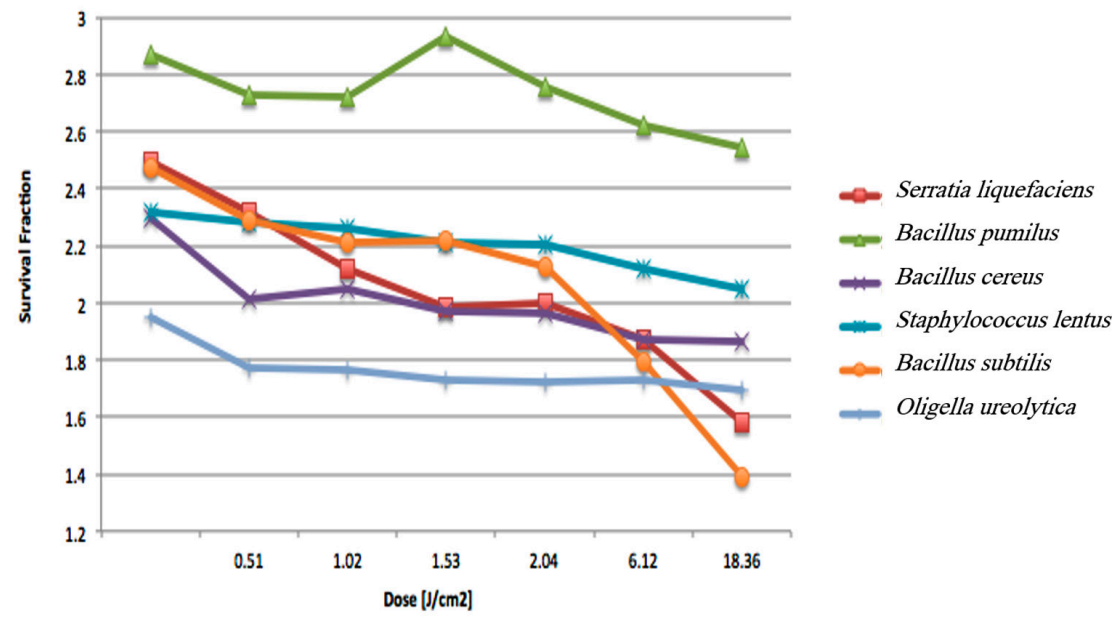

Fig. 2. Survival fraction versus UV dose for the six bacteria isolated from the in-duct of air conditioning systems 
group. follows:

The survival fraction $F_{R}$ was calculated as

$F_{R}=\frac{C_{U V}}{C_{N O U V}}=e^{-Z D}$

$\mathrm{Z}=\frac{1}{\mathrm{D}} \log \frac{\mathrm{C}_{\mathrm{No} \text { uv }}}{\mathrm{C}_{\mathrm{uv}}}$

where, $\mathrm{C}_{\mathrm{Uv}}$ and $\mathrm{C}_{\mathrm{No} \text { uv }}$ are the bacterial concentrations after and before UV irradiation, respectively, $D$ is the dose of UV that the bacteria received, and $\mathrm{Z}$ is the susceptibility expressed in $\left[\mathrm{cm}^{2} / \mathrm{J}\right]$.

\section{Statistical analysis}

Statistical analysis (mean \pm SD) was carried out using the SPSS 16 software to compare the average Z-values. A $p$ value $<0.05$ was considered as being a statistically significant difference (George and Mallery 2016) ${ }^{20}$.

\section{RESULTS AND DISCUSSION}

The results of this study indicated that UV irradiation inhibits the growth of S. liquefaciens,

Table 1. Estimated Z-values for S. liquefaciens, determined at different times at a $15-\mathrm{cm}$ distance of exposure

\begin{tabular}{lccc}
\hline $\begin{array}{l}\text { Time } \\
{[\mathrm{s}]}\end{array}$ & $\begin{array}{c}\text { Dose } \\
{\left[\mathrm{J} / \mathrm{cm}^{2}\right]}\end{array}$ & $\log \frac{\mathrm{C}_{\mathrm{No}}}{\mathrm{C}_{\mathrm{Uv}}}$ & $\begin{array}{l}\text { Z-value } \\
{\left[\mathrm{cm}^{2} / \mathrm{J}\right]}\end{array}$ \\
\hline 300 & 0.51 & 1.09 & $2.141 \pm 0.017$ \\
600 & 1.02 & 1.189 & $1.165 \pm 0.013$ \\
900 & 1.53 & 1.332 & $0.871 \pm 0.014$ \\
1,200 & 2.04 & 1.462 & $0.717 \pm 0.033$ \\
3,600 & 6.12 & 1.443 & $0.236 \pm 0.006$ \\
10,800 & 18.36 & 1.592 & $0.086 \pm 0.000$ \\
21,600 & 36.72 & 2.177 & $0.059 \pm 0.002$ \\
\hline
\end{tabular}

B. subtilis, B. cereus, S. lentus, O. ureolytica, and B. pumilus, and that this inhibition increases upon longer exposure. The irradiance of the UV lamp is a critical variable and influences the bactericidal activity of UV light (Didier et al. 2001) ${ }^{19}$.

The susceptibility values of the bacteria investigated in this study were smaller than those reported in other studies regarding the difference in the light conditions. In a previous study, the $Z$ value of $B$. subtilis was $200 \mathrm{~cm}^{2} / J$ (Rudnick et al. $2009)^{6}$, which is larger than the observation for this bacterium $\left(2.5 \mathrm{~cm}^{2} / \mathrm{J}\right)$ in this study. However, the difference in the $Z$ values could be due to the low UV dose of $0.007509 \mathrm{~J} / \mathrm{cm}^{2}$ used in the previous study compared with the UV dose of $0.51 \mathrm{~J} / \mathrm{cm}^{2}$ used in the current study. The light dose is strongly related to the ability of the bacteria to live longer. Therefore, it makes sense that when the UV dose decreases by two numbers, the Z-value increases by two numbers.

For the Enterobacteriaceae family, Lai et al. $2003^{14}$ reported the susceptibility ( $Z$ value) of Serratia marcescens to be $22000 \mathrm{~cm}^{2} / \mathrm{J}$. In contrast, in this study, Serratia liquefaciens, which also belongs to the Enterobacteriaceae family, showed a Z value of $2.137 \mathrm{~cm}^{2} / J$. The huge difference in the $Z$ values might be attributed to the large difference in the exposure time and the UV dose used. In the previous study, the exposure time was $7.6 \mathrm{~s}$ and the dose used was $0.000342 \mathrm{~J} / \mathrm{cm}^{2}$ Lai et al. $2003^{14}$, whereas in the current study, the exposure time was $300 \mathrm{~s}$ and the dose used was $0.51 \mathrm{~J} / \mathrm{cm}^{2}$.

The $Z$ values indicate the resistance of these bacteria to UV light, with larger $Z$ values suggesting higher resistance. Increasing the time of exposure to the UV light increases the number of photons hitting a bacterial cell, subsequently enhancing the probability of photons reaching the bacterial DNA and damaging it (Courcelle and

Table 2. Z-values for different bacteria for $300 \mathrm{~s}$ of UVGI exposure at 15-cm distance of exposure

\begin{tabular}{|c|c|c|c|}
\hline Microorganism & $\begin{array}{l}\text { Gram } \\
\text { stain }\end{array}$ & $\begin{array}{l}Z \text { value } \\
{\left[\mathrm{cm}^{2} / \mathrm{J}\right]}\end{array}$ & Family \\
\hline Serratia liquefaciens & $-G m$ & $2.141 \pm 0.017$ & Enterobacteriaceae \\
\hline Staphylococcus lentus & $+\mathrm{Gm}$ & $1.858 \pm 0.009$ & Staphylococcaceae \\
\hline Bacillus subtilis & $+\mathrm{Gm}$ & $2.359 \pm 0.061$ & Bacillaceae \\
\hline Bacillus cereus & $+\mathrm{Gm}$ & $2.335 \pm 0.036$ & Bacillaceae \\
\hline Oligella ureolytica & $-G m$ & $2.162 \pm 0.000$ & Alcaligenaceae \\
\hline Bacillus pumilus & $+\mathrm{Gm}$ & $2.944 \pm 0.011$ & Bacillaceae \\
\hline
\end{tabular}


Hanawalt 2001) $)^{9}$. When the UV radiation breaks the bonds in bacterial DNA, a new bond between the nucleotide prevents the replication of DNA and that leads to bacterial cell death. At low doses, cells would not die, but accumulate mutations (Courcelle and Hanawalt 2001) ( $^{9}$ The $Z$ value of $S$. liquefaciens decreased from 2.137 to $0.059 \mathrm{~cm}^{2} / \mathrm{J}$ when the dose of light increased from 0.51 to $36.72 \mathrm{~J} / \mathrm{cm}^{2}$, indicating that the bacteria became more susceptible as the UV dose increased.

The structure of bacteria, particularly the thickness of the cell wall, is an essential factor that significantly affects their airborne survival under the effect of UV radiation. Each bacterium needs to be examined separately for its airborne survival under UV irradiation due to differences in the structure of bacteria (Tang 2009) ${ }^{21}$. Table 2 shows the susceptibility of different gram-negative and gram-positive bacteria, which reflect structural differences among the bacteria; the susceptibility ranged from 1.843 to $2.943 \mathrm{~cm}^{2} / \mathrm{J}$. Notably, gramnegative bacteria, such as $S$. liquefaciens and $O$. ureolytica showed low $Z$ values of 2.137 and $2.162 \mathrm{~cm}^{2} / \mathrm{J}$, respectively, which is likely due to the presence of a thinner cell wall in such bacteria (Beveridge 2009)22. In contrast, the species of the family Bacillaceae, which comprises grampositive bacteria, had the highest $Z$ values and were, therefore, more resistant than the other tested bacteria. Thus, the gram characteristics of a bacterium can help to determine the dose of UV radiation required to inhibit its growth.

\section{CONCLUSION}

The current study indicates that UV irradiation has the ability to reduce air pollution by reducing the concentration of airborne bacteria. This effect of UV depends on the dose of UV used as well as on the bacterial structure. Since multiple bacteria, possibly pathogenic, exist in ducts of air conditioning systems, it would be a good practice to place UV radiation lamps in the duct to sterilize the air passing through the duct and, thereby, minimize or prevent the transmission of airborne bacteria into indoor spaces.

\section{SIGNIFICANCE STATEMENT}

This study discovered that UV radiation can be used inside AC ducts to eliminate the bacteria present inside, which can be beneficial for the indoor environment. This study would help build AC ducts with the exact value of light doses that can prevent bacterial growth and avoid wasting electricity.

\section{ACKNOWLEDGEMENTS}

We thank King Abdulaziz City for Science and Technology for its scientific and financial support to this study A-T-33-174.

\section{CONFLICT OF INTEREST}

The authors declare that there is no conflict of interest.

\section{FUNDING}

This study was supported by the King Abdulaziz City for Science and Technology (A-T33-174).

\section{AUTHORS' CONTRIBUTIONS}

AHA: conceived and designed the experiments, performed the experiments, analyzed the data, prepared figures and/or tables, authored or reviewed drafts of the paper, approved the final draft, contributed reagents/ materials/ analysis tools; SAA: analyzed the data, prepared figures and/or tables, reviewed drafts of the paper, and approved the final draft; HAA: designed and performed experiments, contributed reagents/materials/analysis tools.

\section{DATA AVAILABILITY}

Not applicable.

\section{ETHICS STATEMENT}

Not applicable.

\section{REFERENCES}

1. Thrasher JD, and Crawley S. The biocontaminants and complexity of damp indoor spaces: more than what meets the eyes. Toxicol. Ind. Health, 2009; 25: 583-615. https://doi.org/10.1177/0748233709348386

2. Cowling BJ, Ip DK, Fang VJ, Suntarattiwong $P$, Olsen SJ, Levy J, Uyeki TM, Leung GM, Peiris JM, Chotpitayasunondh $\mathrm{T}$ and Nishiura $\mathrm{H}$. Aerosol transmission is an important mode of influenza $A$ virus spread. Nat. Commun., 2013; 4: 1-6. https://doi. org/10.1038/ncomms2922

3. Antusheva E, Mironuk O, Tarasova I, Eliseev P, Plusnina G, Ridell M, Larsson LO. and Mariyandyshev A. Outbreak of tuberculosis in a closed setting: views 
on transmission based on results from molecular and conventional methods. J. Hosp. Infect., 2016; 93: 187190. https://doi.org/10.1016/j.jhin.2016.02.015

4. Bintsis T, Litopoulou-Tzanetaki E and Robinson R. Existing and potential applications of ultraviolet light in the food industry - a critical review. J. Sci. Food Agric., 2000; 80: 637-645. https://doi.org/10.1002/ (SICI)1097-0010(20000501)80:6\%3C637::AIDJSFA603\%3E3.0.CO;2-1

5. Van Osdell D. and Foarde K. Defining the effectiveness of UV lamps installed in circulating air ductwork. RTI Int., 2002.

6. Rudnick SN, First MW, Vincent RL and Brickner PW. In-place testing of in-duct ultraviolet germicidal irradiation. HVAC \& R., Res. 2009; 15: 525-535. https:// doi.org/10.1080/10789669.2009.10390849

7. Ryan K, McCabe K, Clements N, Hernandez M and Miller S.L., Inactivation of airborne microorganisms using novel ultraviolet radiation sources in reflective flow-through control devices. Aerosol. Sci. Tech., 2010; 44: 541-450. https://doi.org/10.1080/02786821003762411

8. Brickner P, Vincent R, First M, Nardell E, Murray M and Kaufman W. The application of ultraviolet germicidal irradiation to control transmission of airborne disease: bioterrorism countermeasure. Public Health Rep., 2003; 118: 99-114. https://doi.org/10.1093/ $\mathrm{phr} / 118.2 .99$

9. Courcelle $J$ and Hanawalt P. Participation of recombination proteins in rescue of arrested replication forks in UV-irradiated Escherichia coli need not involve recombination. Proc. Natl. Acad. Sci., 2001; 98: 8196-8202. https://doi.org/10.1073/ pnas. 121008898

10. Lopez-Malo A. and Palou E. Ultraviolet light and food preservation. Novel Food Processing Technologies. CRC Press. 2005; 405-21. https://doi. org/10.1201/9780203997277.ch18

11. Kujundzic E, Matalkah F, Howard CJ, Hernandez $\mathrm{M}$ and Miller SL. UV air cleaners and upper-room air ultraviolet germicidal irradiation for controlling airborne bacterial and fungal spores. J. Occup. Environ. Hygiene., 2006; 3: 536-546. https://doi. org/10.1080/15459620600909799

12. Yassin $\mathrm{M}$ and Almouqatea $\mathrm{S}$. Assessment of airborne bacteria and fungi in an indoor and outdoor environment. Int. J. Environ. Sci. Technol., 2010; 7: 535-544. https://doi.org/10.1007/BF03326162

13. Hijnen W, Beerendonk EF and Medema GJ. Inactivation credit of UV radiation for viruses, bacteria and protozoan (oo) cysts in water: a review. Water Res., 2006; 40: 3-22. https://doi.org/10.1016/j. watres.2005.10.030

14. Lai K, Burge $\mathrm{H}$ and First M. Size and UV Germicidal Irradiation susceptibility of Serratia marcescens when aerosolized from different suspending media. Appl. Environ. Microbiol., 2003; 70: 4. https://doi. org/10.1128/AEM.70.4.2021-2027.2004

15. Yang $\mathrm{Y}$, Zhang $\mathrm{H}$, Nunayon SS, Chan $\mathrm{V}$ and Lai ACK. Disinfection efficacy of ultraviolet germicidal irradiation on airborne bacteria in ventilation ducts. Indoor Air, 2018; 28: 806-817. https://doi. org/10.1111/ina.12504

16. Al-abdalall A and Al-abkari H. Microbial contamination of heating, ventilation and air conditioning (HVAC) systems and the efficiency of various filter types in trapping microorganisms in Eastern Saudi Arabia. Asian Int. J. Life Sci., 2017; 26: 283-302.

17. Al-abdalall AH, Al-dakheel SA and Al-Abkari HA. Impact of Air-conditioning Filters on Microbial Growth and Indoor Air Pollution. Intechopen 2019.

18. Al-Abkari H.A. Studies on microbial contamination in air conditioning systems in the Eastern region of Saudi Arabia Kingdom and their control. M.Sc. thesis in Microbiology. Dammam, Saudi Arabia: University of Dammam; 2014.

19. Didier C, Pouget JP, Cadet J, Favier A, Beani J.C. and Richard M.J., Modulation of exogenous and endogenous levels of thioredoxin in human skin fibroblasts prevents DNA damaging effect of ultraviolet A radiation. Free Radical. Biol. Med., 2001; 30: 537546. https://doi.org/10.1016/S0891-5849(00)00502-5

20. George D, Mallery P. IBM SPSS Statistics 23 step by step: A simple guide and reference.14th. Routledge, New York. 2016. https://doi.org/10.4324/9781315545899

21. Tang J, The effect of environmental parameters on the survival of airborne infectious agents. Royal Society, 2009. https://doi.org/10.1098/rsif.2009.0227.focus

22. Beveridge T. Use of the gram stain in microbiology. Biotech. Histochem., 2009; 76: 111-118. https://doi. org/10.1098/rsif.2009.0227.focus 